\title{
COMPILATION OF HANFORD CORROSION STUDIES
}

\author{
David C. Lini
}

Hanford Waste Engineering section

Advanced Waste Engineering Department

Research and Engineering Division

Juily 1975

ATLANTIC RICHFIELD HANFORD COMPANY

RICHLAND, WASHINGTON . 99352
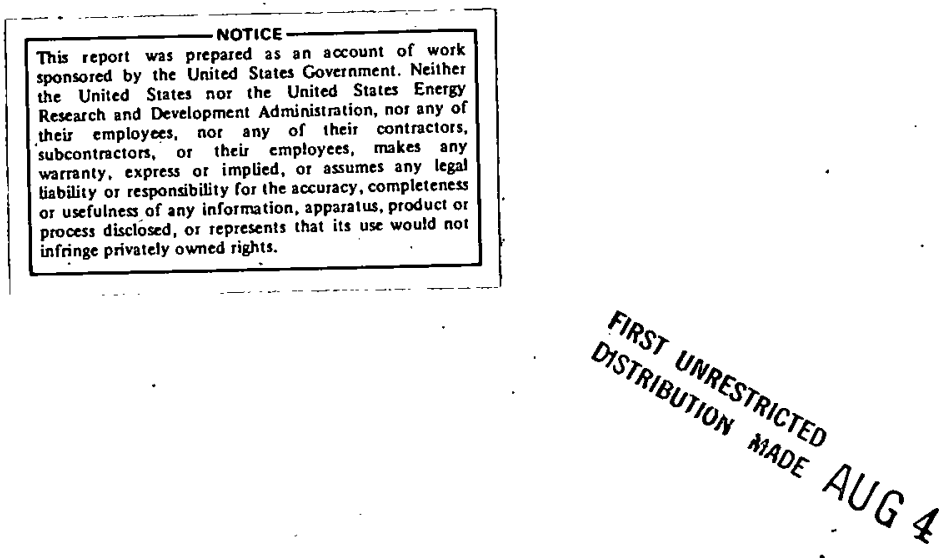


\section{DISCLAIMER}

This report was prepared as an account of work sponsored by an agency of the United States Government. Neither the United States Government nor any agency Thereof, nor any of their employees, makes any warranty, express or implied, or assumes any legal liability or responsibility for the accuracy, completeness, or usefulness of any information, apparatus, product, or process disclosed, or represents that its use would not infringe privately owned rights. Reference herein to any specific commercial product, process, or service by trade name, trademark, manufacturer, or otherwise does not necessarily constitute or imply its endorsement, recommendation, or favoring by the United States Government or any agency thereof. The views and opinions of authors expressed herein do not necessarily state or reflect those of the United States Government or any agency thereof. 


\section{DISCLAIMER}

Portions of this document may be illegible in electronic image products. Images are produced from the best available original document. 
TABLE OF CONTENTS

$\underline{\text { Page }}$

ABSTRACT . . . . . . . . . . . . . . . . . . . . . .

GLOSSERY OF TERMS . . . . . . . . . . . . . . . . . . iv

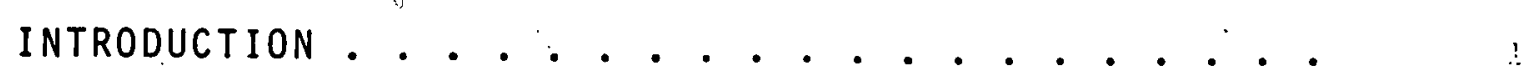

OBJECTIVE . . . . . . . . . . . . . . . . . . . . 1

SUMMARY •. • . . . . . . . . . . . . . . . . . 2

CONCLUSIONS . . . . . . . . . . . . . . . . . . 3

STUDIES ON GENERAL AND PITTING CORROSION .

STRESS CORROSION CRACKING STUDIES . . . . . . . . . . 10

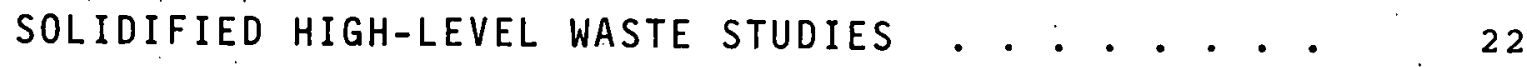

CATHODIC PROTECTION STUDIES . . . . . . . . . . . . . 30

ACKNOWLEDGMENTS . . . . . . . . . . . . . . . . . . 31

REFERENCES • • . . • • . . . . . . . . . . 32 


\section{ABSTRACT}

The aim of this report is to review briefly the experimental Hanford corrosion studies with the inten of identifying the types and rates of corrosion encountered, surveying the experimental techniques used to gather corrosion data, and indicating how these data contribute to tank failure predictions. The experimental studies in this document can be divided into the following areas: general and pitting corrosion, stress corrosion cracking, corrosivity of solidified high-level waste, and cathodic protection. 


\section{GLOSSARY OF TERMS}

Cathodic Protection: A technique to reduce corrosion of a metal surface by passing to it sufficient cathodic current to cause its anodic dissolution rate to become negligible.

Corrosion: The deterioration of a substance or its properties because of a reaction with its environment.

Corrosion Rate: The speed (usually an average) with which corrosion progresses--often expressed as though it were linear.

Cracking: Fracture of a metal in a brittle manner along a single or branched path.

Crevice Corrosion: Localized corrosion resulting from the formation of a concentration cell in a crevice formed between a metal and a nonmetal or between two metal surfaces.

Environment: The surroundings or conditions (physical chemical, mechanical) in which a material exists.

General Corrosion: corrosion in a uniform manner.

Measuring Corrosion:

General Corrosion

1. Weight change--weight loss or gain per unit area per unit time. Common measure "milligrams per square decimeter per day" (mad).

2. Weight loss--loss of metal thickness per unit time. commonly used unit is "mils per year" (mpy) or "inches per month" (ipm).

Pitting

1. Penetration--depth of maximum or average pit in inches or mils per unit time or total time of exposure.

2. Number of pits per unit area.

Mild Steel: Nonresulfurized, low-carbon steel. Generally designated by AISI number loxx. The $x X$ indicates nominal carbon content within range. The usual range 
is 0.20 to 0.35 wt 8 , although there are 44 compositional ranges from 1008 to 1095. Manganese ranges from 0.30 to $1.65 \mathrm{wt}$ if specified silicon is 0.10 to $0.30 \mathrm{wt} 8$ maximum. Phosphorus is 0.040 wt: maximum and sulfur is 0.050 wto maximum.

Mil: One-thousandth of an inch.

Passivity: The loss of chemical activity exhibited by metals and alloys under specific environmental conditions.

pH: A measure of the acidity or alkalinity of a solution. A value of 7 is neutral; low numbers are acid--large numbers are alkaline.

Pitting Corrosion: Highly localized corrosion resulting in deep penetration at only a few spots.

Spheroidizing: Any process of heating and cooling that produces a rounded or globular form of carbide in steel.

Strain: A measure of the change in dimensions of a material when loaded compared with its original size or shape. For example, linear strain would be the change in length of a part compared with the original length. It is usually expressed as a percentage or in inches per inch.

Stress: Load or force per unit area of the cross-section through which the load is acting. An equation form is:

$$
\text { Stress = load/area }(S=L / A) \text {. }
$$

Stress Corrosion: Corrosion which is accelerated by stress.

Stress Corrosion Cracking: Premature cracking of a metal produced by the combined actions of corrosion and surface tensile stress (residual or applied).

Yield Point: The stress on a material at which the first significant plastic or permanent deformation occurs without an increase in stress.

Yield Strength: The stress which causes a specified deviation from elastic dimension (usually 0.28 ). 
ARH-ST-III

\section{COMPILATION OF HANFORD CORROSION STUDIES}

\section{INTRODUCTION}

The Hanford radioactive processing waste, after neutralization with aqueous sodium hydroxide, is stored in underground storage tanks constructed of reinforced concrete containing a mild steel liner. This decision was based in part on results of laboratory corrosion studies conducted at the clinton Laboratory. [1]

Since the mild steel liner was the primary containment: vessel, corrosion studies conducted at Hanford have investigated the consequences and ramifications of this decision. The studies generally were conducted in the laboratory using neutralized, synthetic, nonradioactive waste as the corrodent. In only a few cases were radioactive wastes used or in-tank. studies conducted. Test coupons were fabricated from various types of mild steel and included a variety of configurations. When stress corrosion cracking was identified as a possible mode of tank-liner failure, stressed and precracked coupons were included in the testing program.

\section{OBJECTIVES}

The aim of this report is to review briefly the experimental Hanford corrosion studies with the purpose of identifying the types and rates of corrosion encountered, surveying the experimental techniques used to gather corrosion data, and indicating how these data contribute to tank failure predictions. Since the existing waste storage tanks will be used to store the salt cake waste generated by the evaporation of water from the liquid waste, the present condition of the tanks is of interest; and a review of previous 
corrosion studies will give some insight into the present condition of the tanks.

\section{SUMMARY}

The early laboratory corrosion studies were conducted using coupon immersion tests. A variety of mild steel was exposed to simulated waste environments for varying periods of time. The results indicate that the rate of generai. corrosion is at a rate that is reasonable for the storage of a caustic-nitrate solution in mild steel containers. Data on pitting corrosion are difficult to interpret and correlate, consequently they have not been as useful as a predictive technique.

A few in-tank studies were made in which test coupons were exposed to the actual waste tank environment. The results of these studies tend to confirm the bulk of the laboratory experiments on general and pitting corrosion.

As a result of some premature failures at Hanford and Savannah River, it became apparent that stress corrosion cracking (SCC) was the most likely cause for failure. At both facilities conditions are favorable for this type of failure; namely, residual stress in the weld areas, nitrate ion in the waste solution, and elevated temperatures. The bulk of the subsequent experimental effort has been directed toward investigating the conditions for SCC.

Maness and later Moore amply demonstrated that the sodium nitrate concentrations found in high-level liquid waste $(5-8 \mathrm{~N})$ are sufficient to cause stress corrosion cracking in the mild steel liners at the temperatures $\left(>100^{\circ} \mathrm{C}\right)$ the waste is stored. For specimens stressed to levels approaching 1008 of yield or precracked, cracking zones 
could be identified.

The corrosion studies were extended to include the corrosive effect of simulated salt cake. Long-term immersion tests are presently being conducted. The initial result indicates that the rate or severity of corrosion might be different from that encountered with the liquid wastes, but the failure modes are the same.

Two methods that can prevent cracking have been proposed and demonstrated. Cracking can be prevented by annealing the mild steel or by the application of cathodic protection. All new double-shelled storage tanks are routinely thermally stressed-annealed to relieve residual stresses. Cathodic protection is currently under investigation as a means of decreasing the rate of corrosion of the steel tank liners.

\section{CONCLUSIONS}

This compilation does not include all the experimental studies conducted at Hanford over the last 30 years. It does review the type of work that was done, the kinds of results that were obtained, and how these data contribute to evaluating tank lifetimes.

Stress corrosion cracking has been the most serious threat to the integrity of the mild steel liner. The results of E. L. Moore and R. F. Maness indicate that a sodium nitrate solution will cause stress corrosion cracking of stressed mild steel at elevated temperatures. The three variables are interdependent, but at a temperature near $100^{\circ} \mathrm{C}$ and a stress of 50 to $100 \%$ of yield strength, the concentration of nitrate ion which will cause stress cracking is 6 to $8 \mathrm{~N}$. They also showed that sodium.hydroxide, sodium 
nitrite, and sodium sulfate will inhibit nitrate cracking. Under certain conditions sodium hydroxide will cause stress corrosion cracking in a manner analogous to nitrate cracking.

Pitting attack is more severe on mild steel exposed to simulated solidified caustic waste than on mild steel exposed to simulated liquid waste. Both the average pit depth and maximum pit depth have increased by at least a factor of two.

Laboratory experiments have not indicated that pitting corrosion is more severe at the liquid/air interface than in the liquid phase. This is in contrast to conclusions based on the interpretation of tank failure data which suggests that interfacial pitting corrosion was responsible for some premature tank liner failures.

It is extremely difficult to extrapolate pitting data to predict failure times. Not only are the deepest pits (which will cause the first failure) significant, but also the average depth of the pits, the number of pits per unit area, the growth rate of the pits, and the shape of the pits. Consequently the data have not been useful in establishing criteria for predicting tank lifetime.

of the corrosion modes encountered, general corrosion is the least serious threat to tank integrity. The rate of corrosion of the mild steel is low and reasonable for the storage of hot caustic-nitrate solutions. The rate is higher for mild steel specimens exposed to hot simulated salt cake than for those specimens exposed to liquid waste. This is an understandable consequence of concentrating the aggressive components in simulated salt cake.

Techniques have been proposed and demonstrated that 
decrease the propensity for premature tank failure-stress relief of the mild steel liner by thermally annealing the metal and the application of cathodic protection.

Stress relief eliminates the threat of cracking by removing one of the necessary conditions for stress corrosion cracking; $i . e$. , the stress. The inner tank of all new double-walled storage tanks is thermally stress-relieved. This type of tank has been in operation since 1967 at both the Energy Research and Development Administration Savannah River and Hanford sites and no failures from stress cracking have been reported for these tanks.

Cathodic protection has been widely employed for corrosion control and would be a positive means of increasing the lifetime of the tanks.

Preliminary experiments using simulated liquid waste and nitrate solutions have demonstrated that cathodic protection can prevent stress corrosion cracking. Studies are currently in progress to determine the effectiveness of cathodic protection to protect mild steel in the presence of salt cake. There are, however, a number of chemical, electrochemical and mechanical questions to be answered to determine the feasibility of this approach.

Corrosion studies cannot predict when a particular tank at Hanford will fail. Corrosion studies can and will indicate those conditions that accelerate corrosion and lead to - premature tank failure. With this information one can establish storage criteria to minimize environmental effects, design engineered improvements of existing tanks, and design alternate methods of storage. 


\section{STUDIES ON GENERAL AND PITTING CORROSION}

The early reports $[2-8]$ using SAE 1010 and 1020 steel confirmed that at $\mathrm{pH}>10$ and temperatures $c a .100^{\circ} \mathrm{C}$ $\left(220^{\circ} \mathrm{F}\right)$ there was little general corrosion. Extensive pitting corrosion was observed on that portion of the mild steel coupon exposed to the vapors $(1.8$ mils after 24 hours). The effects of $\mathrm{pH}$ were also investigated and it was concluded that there were no ill effects in lowering the $\mathrm{pH}$ from 9 to 7--at pH 6 there was extensive pitting corrosion of the metal exposed to the vapors. Olson[7] reported a maximum rate of general corrosion of $48 \times 10^{-5}$ inches/month (6 mils/year) for a $1 \times 10^{3}$-hour test at $100^{\circ} \mathrm{C}$. The range observed was 0.3 to $48 \times 10^{-5} \mathrm{ipm}$. Further, he observed no pitting corrosion and no evidence for accelerated cörrosion at the liquid vapor interface. The effect of temperature and $\mathrm{pH}$ is summarized in Table $I$. Olson concluded that at a

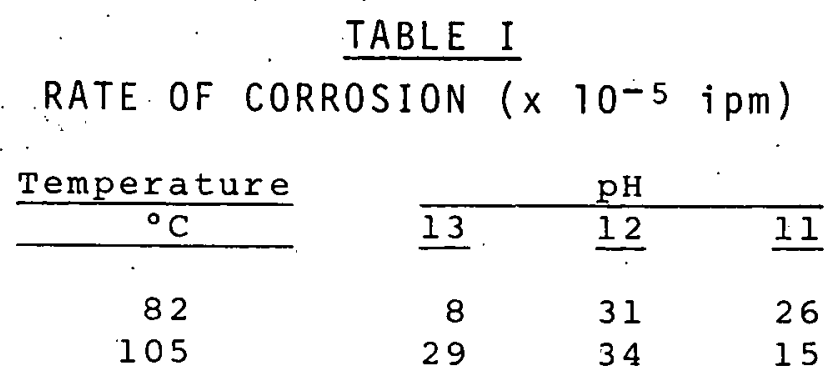

uniform rate of corrosion of $6 \mathrm{mils} /$ year, one-half the wall thickness of a 3/8" steel tank would be removed in 30 years. Since this is the maximum rate observed, it reflects the worst case whereas the range covers two orders of magnitude. The effect of $\mathrm{pH}$, as shown above, is rather inconclusive as is the effect of temperature. The solutions at $\mathrm{pH} 12$ and 13 contained solids which caused nonuniform heat distribution and higher sludge temperatures $\left(>100^{\circ} \mathrm{C}--200^{\circ} \mathrm{F}\right)$ as 
reflected by the higher corrosion values.

Additional laboratory testing[8] over a six-week period of time at $121^{\circ} \mathrm{C}\left(250^{\circ} \mathrm{F}\right)$ and $\mathrm{pH} 13$ resulted in a general corrosion rate of $0.6 \mathrm{mpy}$ for a sample of SAE 1010 steel. In this study pitting was observed around the stressed area of the coupon. A pitting rate of $4.8 \mathrm{mpy}$ was reported with the rate decreasing with time. The report does not indicate if these were the maximum pit depth, the average depth, etc. Further, it is dangerous to report a rate for pit corrosion since as in this case the rate is decreasing with time. It is more correct just to report pit depth as of that time and not extrapolate to per year. The maximum pit depths observed in this and a subsequent report [9] were $3.8 \mathrm{mils}$ after 10 months and $2.8 \mathrm{mils}$ (range 0.8 to $2.8 \mathrm{mils}$ ). In the latter report the experimental details and exposure time were not furnished. Also, irradiated samples were used but nothing unusual was reported. No evidence of stress corrosion cracking was observed. Another report on pitting corrosion also does not report the time of the experiment but has the following data. The tests do show that pitting corrosion is more of a problem in the liquid, particularly around the welded and stressed areas of the tank, than general corrosion. .

TABLE I I

MAXIMUM PITTING PENETRATION (mpy)

SAE 1020 SAE 1020 Transverse Weld Weld and Stress Stress

$\begin{array}{llllll}\text { Vapor } & 2.075 & 1.885 & 1.380 & 1.680 & 1.680 \\ \text { Liquid } & 6.420 & 6.420 & 9.643 & 8.250 & 7.719\end{array}$

These early reports are inconclusive but indicate that the rate of general corrosion is reasonable for the storage of caustic liquid in mild steel containers. The pitting 
data are inconclusive and interpretation is not easy. Pitting data are always difficult to interpret since sample configuration, pits/unit area, average depth; maximum depth, and time are all important and need to be defined.

In most of the laboratory tests using simulated waste the effect of $\mathrm{pH}$ has received the most attention. The Clinton Laboratory report indicated that the waste solution could be adequately stored at $\mathrm{pH}$ 10; but by lowering the $\mathrm{pH}$ to 7 to 9, the total volume of stored waste would be less and this would be more economical--which at the time was their main concern. The other environmental factors were pseudo-invariant and therefore not variables to be studied. The rate or nature of corrosion as a function of one of the constituents was not as important as the total effect of the waste on the steel liner.

In situ tank studies on the rate of corrosion of mild steel coupons have been conducted periodical1y. $\left[\begin{array}{ll}1 & 1-1\end{array}\right]$ Two types of specimens of SAE 1020 carbon steel specimens were exposed to the boiling waste solution in Tank 104 of the S-Waste Storage Tank Farm for nine months. The coupons were placed in the sludge layer approximately 2' from the bottom of the tank. The temperature should have been in excess of $121^{\circ} \mathrm{C}\left(250^{\circ} \mathrm{F}\right)$. The U-bend specimen did not show any evidence of stress corrosion cracking. The maximum rate of general corrosion was $4.7 \times 10^{-5}$ inches/month (0.56 mpy). The rates for the three unstressed specimens were $3,4.5$, and $4.7 \times 10^{-5} \mathrm{ipm}$. [11-12] A corresponding laboratory study [7] conducted simultaneously found the rate of general corrosion of SAE 1020 carbon steel to be $5 \times 10^{-5}$ ipm. The deepest pit found was 4 mils; the range of pitting depth observed was 2.1 to $4 \mathrm{mils}$. This study tends to confirm the bulk of the laboratory studies on general and pitting 
corrosion of the mild steel immersed in the waste solution.

A similar study was made employing the 241-TX Tanks 105, 109, and 117, which contained Bismuth Prosphate Process Waste. $[13,14]$ Only one type of specimen was used, but the. specimens were exposed both to the liquid waste and the vapor above the waste. The first set of specimens was placed 10 to $15^{\prime}$ into the tanks, while the second set was placed at the 35' level.

Tank 105 contained metal waste solution, Tank 109 first-cycle waste, and Tank 117 first-cycle concentrate. The samples were recovered after 5,400 hours' exposure ( 7 months). Only tank samples were recovered from Tank 109, only vapor samples from Tank 105, and no samples were recovered from Tank 117. The results confirm that general corrosion is not a problem in the liquid waste $\left(2 \times 10^{-5}\right.$ ipm in Tank 109). However the vapors in Tank 105 severely attacked the specimen, resulting in a $4.5 \%$ weight loss and severe pitting corrosion. The deepest pit was 11 mils with an average of 6 mils. This would give a rate of pitting of $18 \mathrm{mpy}$ (based on a 5,400-hour test). A laboratory study reported a pitting rate of $21.6 \mathrm{mpy}$ with the deepest pit 3.1 mils (424-hour test). This indicates the rate of pitting is decreasing; and also shows the dangers of reporting pitting rates rather than the pit depth as a function of time of test.

A recent [15] report confirms these earlier studies and again demonstrates that general corrosion is not the problem. Specimens of A-283 mild steel were exposed for 736 days to simulated boiling alkaline high-level waste solutions, both fluoride-bearing (Zircaloy-clad fuels - ZWW) and fluoride-free (Al-clad fuels - $1 W W$ ).

On a weight loss basis (general corrosion) the 
specimens corroded at a rate of $0.06 \mathrm{mpy}$ (IWW) and $0.02 \mathrm{mpy}$ (zWW). Further, preferential attack at the vapor-liquid interface was not observed in either case. Pitting attack on both specimens. was more intense on that part exposed to the vapor phase. The maximum pit depth observed at any location was $<5$ mils which is not inconsistent with the earlier reports, and over a longer period of time... Interrestingly a rather severe crevice corrosion was observed near the bottom edge of both specimens, probably because of the way the coupons were placed in the Teflon container.

Besides the corrosion studies on the mild steel liners, corrosion studies were made to test the steel used in the reinforcing bars. [16-17] The tests were 3 weeks and 4.5 months in duration at $111^{\circ} \mathrm{C}\left(230^{\circ} \mathrm{F}\right)$. In both cases no change in tensile strength, no cracks, and little corrosion were observed. Some minor pitting corrosion was noted in the steel wire exposed to the vapors.

\section{STRESS CORROSION CRACKING STUDIES}

An investigation of some premature tank failures at Hanford and Savannah River indicated that stress corrosion cracking (SCC) was the most likely cause for the leaks. Conditions at both facilities are favorable for this type of corrosion; namely, residual stresses in weld areas, nitrate ion in the waste solution, and elevated temperatures.

Failures have been reported due to pitting corrosion at the vapor-liquid interface, mechanical failure, and bulged liner bottoms. However, stress corrosion cracking would appear to be a more serious corrosion threat since pitting corrosion is reported to be less serious in mild steel than other steels and metals, and the mechanical failures are unique. The bulk of the experimental effort at Hanford and 
particularly Savannah River has been directed at investiating the conditions for SCC.

To substantiate that nitrate ion was the cause of the stress corrosion cracking being observed in the waste storage tanks, R. F. Maness[18] carried out a series of laboratory- and pilot-scale tests to evaluate the effects of sodium nitrate $\left(\mathrm{NaNO}_{3}\right)$ and/or ammonium nitrate $\left(\mathrm{NH}_{4} \mathrm{NO}_{3}\right)$ on the cracking propensity of mild steel specimens. Several important and far-reaching conclusions were made in this report.

- It was shown that different results can be obtained depending on the choice of specimen size, configuration, and stress mode.

- These tests confirm that the weldment areas are subject to cracking by nitrate ion $\left(\mathrm{NO}_{3}{ }^{-}\right)$.

- Cracking can be prevented by annealing or by cathodic protection.

These results are confirmed by the subsequent work carried out by Moore[1 9 ] and at Savannah River. [ $\left.\begin{array}{ll}2 & 0\end{array}\right]$

Laboratory-scale experiments were made with c-ring specimens (American Society for Testing and Materials A-106) and with notched and stressed (bent-beam) specimens (ASTM A-201-57 grade $B, A-201-B$, and A-2.83-59 grade $C$ at two carbon levels). The experimental conditions and the results of the $C$ ring tests are summarized in Table III. Results of the tests with bent-beam specimens are given in Table IV. These samples were not precracked, so the time to failure includes both the rate of crack initiation and the rate of crack growth. 
TABLE I I I

LABORATORY-SCALE TESTS USING C-RING SPECIMENS

Samples: C-Ring Specimens (ASTM A-106)

a. Notched $20.025^{\prime \prime}$ deep $45^{\circ}$ at line of maximum stress.

b. Cut and welded at the line of maximum stress.

\section{Treatment}

a. As fabricated.

b. Spheroidizing heat treatment at $700^{\circ} \mathrm{C}$.

c. Water queriching at $800^{\circ}$ to $900^{\circ} \mathrm{C}$.

Stress Levels

a. Varied from 50 to ioo: of yield.

\section{Corrodents}

a. 50 wto $\mathrm{NaNO}_{3}$.

b. Synthetic alkaline Purex waste ( $6 \mathrm{~N} \mathrm{NO}_{3}{ }^{-}$).

c. Synthetic formaldehyde-treated alkaline purex waste. ( 1 N $\left.\mathrm{NO}_{3}^{-}\right)$.

d. Synthetic coating removal waste.

Conditions

a. Temperature: at or near boiling point.

b. Time of exposure: 2 to 15 months.

\section{Results}

a. None of the specimens failed in synthetic waste solution:

b: Failure in 50\% NaNo was as follows:

- The as-fabricated specimens required severe plastic deformation.

- About 50\% of the water-quenched specimens failed at or near $100 \%$ of yield.

- Spheroidizing heat treatment in excess of 20 hr increased the propensity to crack. 
TABLE IV

STRESS CORROSION CRACKING RESULTS

WITH NOTCHED, BENT-BEAM SPECIMENS

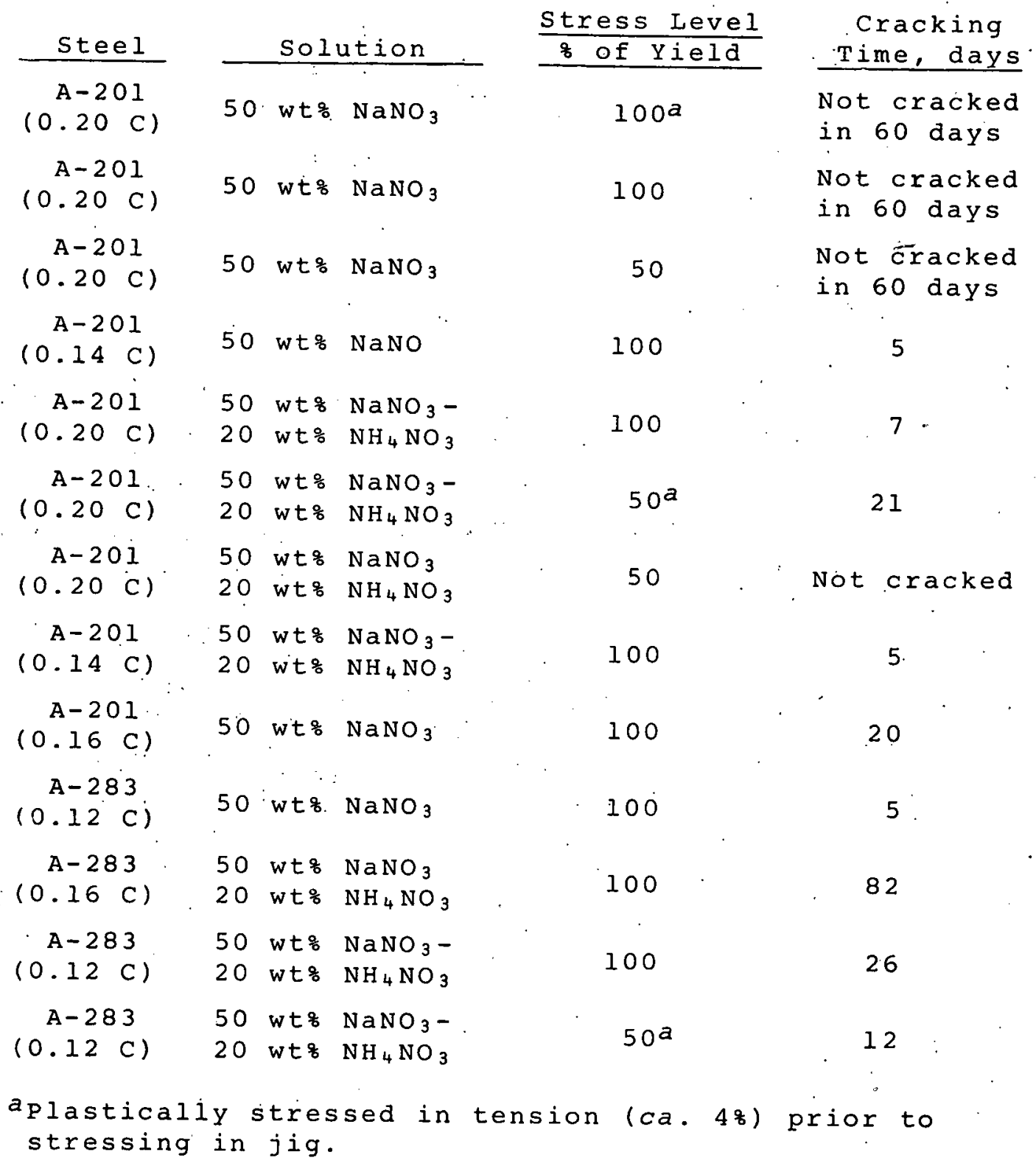


The effect of applying cathodic protection to a stressed specimen was also evaluated in this work. The results are shown below for specimens of A-283, grade C $(0.16 \mathrm{C})$ stressed to $100 \%$ of yield and exposed to $50 \mathrm{wt} \%$ NaNO at $90^{\circ} \mathrm{C}$.

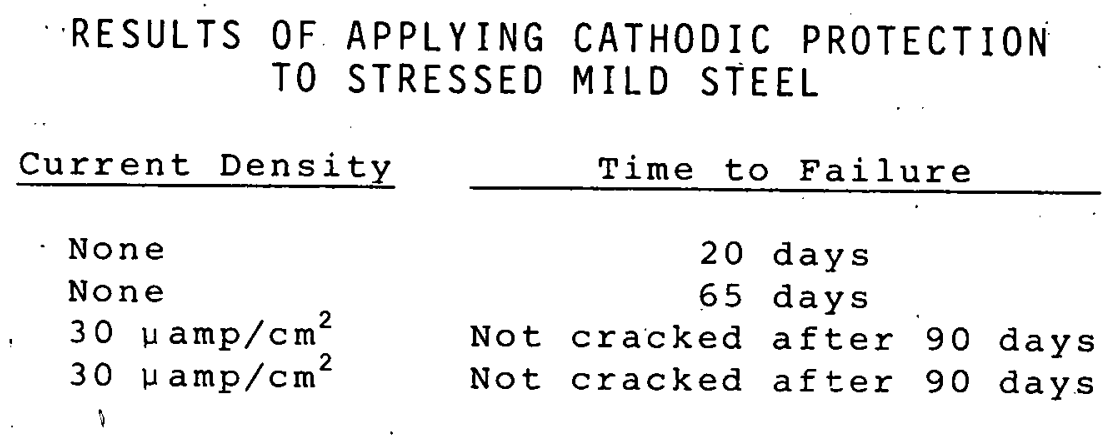

The results of the laboratory-scale experiments with mild steel in nitrate solutions indicate that: ASTM A-201-57T, grade $B$, appears to offer the greatest resistance to crack initiation (of the metals tested); cracking susceptibility in mild steel is inversely proportional to the carbon content (in the range of 0.04 to 0.25 wto); cathodic protection can guard against cracking of suspectible steels; and that the susceptibility of mild steels to SCC is increased by plastic deformation, spheroidizing heat treatments, and the presence of ammonium ion in nitrate solution.

Pilot-scale tests were made using $3^{\prime} \times 3^{\prime}$ weldments $3 / 8$ to 5/8" thick as the specimens. The test variables and test results are summarized in Table $\mathrm{V}$. All weldments tested in 50 wto $\mathrm{NaNO}_{3}$ and 40 wt: $\mathrm{NaNO}_{3}-10$ wto $\mathrm{NaNO}_{2}$ failed. These results confirmed the laboratory-scale test with the A-293 bent-beam specimens. But more importantly, the weldments exposed to synthetic alkaline Purex waste $\left(6 \mathrm{~N} \mathrm{NO}_{3}{ }^{-}\right)$are susceptible to SCC regardless of the steel or the filler metal. The weld repair areas were reported to be especially susceptible to crack initiation. The C-ring coupons (A-106 steel) were immune to SCC in simulated Purex wastes even 


\section{TABLE V}

\section{SUMMARY OF PILOT-SCALE WELDMENT EXPOSURES}

Plate Mate
A-283, Grade C
A-283, Grade C
A-283, Grade C
A-283, Grade C
A-283, Grade C
A-283, Grade C
A-283, Grade C
A-283, Grade C
A-283, Grade C
A-283, Grade C
A-283, Grade C
A-283, Grade C
A201-57T, Grade

A201-57T, Grade B A201-57T, Grade B A-201, Grade B

$$
r
$$

Welding Rod

6016

6016

Inconei 18

6016

6016

Inconel 182

$6016^{a}$

$(0.12 \mathrm{c})$

$(0.16 \mathrm{C})$

$(0.16 \mathrm{C})$

$(0.12 \mathrm{C})$

$(0.16 \mathrm{C})$

$(0.16 \mathrm{C})$

$(0.20 \mathrm{C})$

$\left(0.20^{\circ} \mathrm{C}\right)$

$(0.20 \mathrm{c})$

$(0.14 \mathrm{C}$, Inconel 18

6010

6010

6010

6010
Solution

50. $w \mathrm{t} 8 \mathrm{NaNO}_{3}$

50. wt: $\mathrm{NaNO}_{3}$

50 wt\& $\mathrm{NaNO}_{3}$

40. wto $\mathrm{NaNO}_{3}-10$ wt\& $\mathrm{NaNO}_{2}$

40 wtz $\mathrm{NaNO}_{3}-10$ wt8 $\mathrm{NaNO}_{2}$

40 wt8 $\mathrm{NaNO}_{3}-10$ wt8 $\mathrm{NaNO}_{2}$

Synthetic Purex waste $\left(6 \mathrm{~N} \mathrm{NO}_{3}{ }^{-}\right)$

Synthetic Purex waste $\left(6 \mathrm{~N}_{\mathrm{NO}_{3}}{ }^{-}\right)$

Synthetic Purex waste $\left(6 \mathrm{~N} \mathrm{NO}_{3}{ }^{-}\right)$ Synthetic Purex waste $\left(6 \mathrm{~N} \mathrm{NO}_{3}{ }^{-}\right)$

Synthetic Purex waste $\left(6 \mathrm{~N} \mathrm{NO}_{3}{ }^{-}\right)$ Synthetic Purex Waste $\left(6 \mathrm{~N} \mathrm{\textrm {NO } _ { 3 }}{ }^{-}\right)$ Synthetic Purex Waste $\left(6 \mathrm{~N} \mathrm{NO}_{3}{ }^{-}\right)$

Synthetic Purex waste $\left(6 \mathrm{~N} \mathrm{NO}_{3}-\right)$ Synthetic Purex waste $\left(6 \mathrm{~N} \mathrm{NO}_{3}{ }^{-}\right)$ Synthetic Purex Waste $\left(6 \mathrm{~N} \mathrm{NO}_{3}^{-}\right)$
Weld Repair Area. No

No

No

Yes

Yes

Yes. 81 days prior

to failure

Yes 81 days prior

to failure.

No

No

No

No

Yes 67 days prior

to failure

Yes

$a^{3 "}$ beads of $958 \mathrm{Cd}-58 \mathrm{Ag}$ alloy at $6 "$ intervals, deposited adjacent to all seam welds.

Initial 30 days' exposure to synthetic formaldehyde-treated alkaline waste (about IM nitrate).

Approximate Cracking Time, days

.90

90

90

80

80

80

165

165

265 , not cracked

42

42

248 , not cracked

$298^{b}$

73, not cracked

73, not cracked

No inspection to dațe 
though highly stressed. This again demonstrates the importance of choosing a test and evaluation procedure that is suitable for a specific purpose.

Moore $\left[\begin{array}{ll}19 & \end{array}\right.$ conducted an investigation to evaluate the effect of welding method, stress relief treatment, and plate thickness on the stress corrosion cracking tendency of ASTM A-515 grade 60 carbon steel plate exposed to $5 \mathrm{M} \mathrm{NaNO}_{3}$. In six to eight weeks the longitudinally welded restrained plates cracked adjacent to the welds. The largest number of cracks occurred at repair welds. No cracks occurred in thermally stressed relieved specimens. The extent of cracking was designated only on the basis of visual observation.

Stress corrosion cracking also occurred in a welded specimen ("big plates") exposed to heated $4 M \mathrm{NO}_{3}{ }^{-}+1 \mathrm{M} \mathrm{NO}_{2}{ }^{-}$ but was not observed in specimens exposed for two years in $3 M \mathrm{NO}_{3}^{-}+2 M \mathrm{NO}_{2}-\left[\begin{array}{lll}2 & 1-2 \cdot 2\end{array}\right]$. (Table VI).

TABLE VI

STRESS CORROSION CRACKING IN NITRATE-NITRITE SYSTEM (pH 9.5)

$\begin{array}{ccc}\frac{\text { Solution }}{\mathrm{NaNO}_{3}} & \frac{\text { Molarity }}{\mathrm{NaNO}_{2}} & \text { Cracking Time } \\ 4 & 1 & <8 \text { weeks } \\ 3 & 2 & >2 \text { years } \\ 2 & 3 & >2 \text { years } \\ 1 & 4 & >2 \text { years } \\ 4 * & 2 * & >6 \text { months } \\ \text { *Plus } 0.25 \mathrm{M} \mathrm{Na}_{2} \mathrm{SO}_{4} . & \end{array}$

Sulfate[22-25] ion at $0.75 M$ and $I M$ also inhibits cracking in welded "big plates" ( $1^{\prime} \times 3^{\prime} \times 2^{\prime \prime}$ ) exposed in $5 M \mathrm{NaNO}_{3}$ at $\mathrm{pH} 10$ for eight weeks. However, cracks were observed in one of two specimens exposed in $0.5 \mathrm{M}$ sulfate-5M $\mathrm{NaNO}_{3}$ 
solution. All restraining bars (three per weldment) were cracked on the two weldments exposed to $5 M \mathrm{NaNO}_{3}-0.25 \mathrm{M} \mathrm{Na}_{2} \mathrm{SO}_{4}$ solution.

The work of both Maness[18] and Moore[19] amply demonstrates that a sodium nitrate solution will cause stress corrosion cracking of stressed mild steel at elevated temperature. The three variables are interdependent; but at a temperature near $100^{\circ} \mathrm{C}$ and a stress of 50 to $100 \%$ of yield, the concentration of nitrate ion which will cause cracking is 6 to $8 N$.

An accelerated test utilizing precracked mild steel C-rings fabricated from 0.5" lengths of 1.25 " diameter schedule 80 pipe (ASTM A-106, Grade B) was used to evaluate stress corrosion cracking in the nitrate system. [26] The test is accelerated since a precracked specimen is used, and the time-to-failure measures the rate of propagation of the crack and ignores the rate of initiation. Conditions for crack initiation are not necessarily the same as the conditions for crack propagation. However flaws, scratches, etc., exist in the large welded steel tanks containing. salt cake or waste liquid and the rate of crack propagation is more meaningfui than the rate of crack initiation. Prestressed C-ring specimens were used rather than weldment specimens to introduce the stress factors in the tests. The c-rings are smaller and easier to handle than the large. welded plates, and the individual specimens are more reproducible.

Variables which were evaluated include nitrate concentration, nitrite concentration, temperature, nature of the condenser system, the presence of air, the effect of oxidants, pH, sulfate concentration, and acetate content.

The results of these tests are shown in Table VII. 
TABLE VII

STRESS CORROSION CRACKING STUDIES: PRE-CRACKED C-RING

(Mild Steel - Nitrate System)

\begin{tabular}{|c|c|}
\hline $\begin{array}{l}\text { Run } \\
\text { No. }\end{array}$ & Solution \\
\hline 1 & $10 \mathrm{M} \mathrm{NaNO}_{3}$ \\
\hline 2 & $8 \mathrm{M} \mathrm{NaNO}_{3}$ \\
\hline 3 & $8 M \mathrm{NaNO}_{3}$ \\
\hline 4 & $5 M \mathrm{NaNO}_{3}$ \\
\hline 5 & $5 \mathrm{M} \mathrm{NaNO}_{3}$ \\
\hline 7 & $5 \mathrm{~N} \mathrm{NaNO}_{3}$ \\
\hline 8 & $5 \mathrm{M} \mathrm{NaNO}$ \\
\hline 9 & $5 \dot{M} \mathrm{NaNO}_{3}$ \\
\hline 10 & $10 M \mathrm{NaNO}_{3}$ \\
\hline 11 & $10 M \mathrm{NaNO}_{3}$ \\
\hline 12 & $4 M \mathrm{NaNO}_{3}$ \\
\hline 13 & $4 M \mathrm{NaNO}_{3}$ \\
\hline 14 & $3 M \mathrm{NaNO}_{3}$ \\
\hline 15 & $3 M \mathrm{NaNO}_{3}$ \\
\hline 16 & $2 \mathrm{M} \mathrm{NaNO}_{3}$ \\
\hline 18 & 1. $5 \mathrm{M} \mathrm{NaNO}_{3}$ \\
\hline 19 & $1.0 M \mathrm{NaNO}_{3}$ \\
\hline 20 & $0.5 \mathrm{M} \mathrm{NaNO}$ \\
\hline 21 & $0.25 \mathrm{M} \mathrm{NaNO}$ \\
\hline 22 & $0.05 \mathrm{M} \mathrm{NaNO}$ \\
\hline 23 & $5 M \mathrm{NaNO}_{3}$ \\
\hline 24 & $5 M \mathrm{NaNO}_{3}$ \\
\hline 25 & $5 M \mathrm{NaNO}_{3}$ (tap water) \\
\hline 26 & $\begin{aligned} & 5 \mathrm{M} \mathrm{NaNO}_{3} \text { (air sparge in } \\
& \text { liquid phase) }\end{aligned}$ \\
\hline 27 & 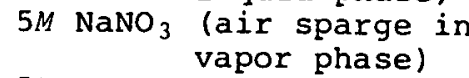 \\
\hline 28 & $5 M \mathrm{NaNO}_{3}-0.01 \mathrm{M} \mathrm{NaNO}_{2}$ \\
\hline 29 & $5 \mathrm{M} \mathrm{NaNO}_{3}-0.10 \mathrm{M} \mathrm{NaNO}_{2}$ \\
\hline 30 & $5 \mathrm{M} \mathrm{NaNO}_{3}-1 \mathrm{M} \mathrm{NaNO}_{2}$ \\
\hline 31 & $6 \mathrm{M} \mathrm{NaNO}_{3}-0.001 \mathrm{M} \mathrm{SrO}_{3}$ \\
\hline 32 & $5 M \mathrm{NaNO}_{3}-0.10 \mathrm{M} \mathrm{SrO}_{3}$ \\
\hline 33 & $8 M \mathrm{NaNO}_{3}-1 \mathrm{M} \mathrm{NaNO}_{2}$ \\
\hline 3 & $5 M \mathrm{NaNO}_{1}-0.01 M \mathrm{Na}_{2} \mathrm{C}_{2} \mathrm{O}_{4}$ \\
\hline
\end{tabular}

\begin{tabular}{|c|c|c|}
\hline $\begin{array}{c}\text { Initial } \\
\mathrm{pH}\end{array}$ & $\begin{array}{c}\text { Terminal } \\
\mathrm{pH} \\
\end{array}$ & $\frac{\text { Temperatu }}{{ }^{\circ} \mathrm{C}}$ \\
\hline 6.6 & 6.6 & Boiling \\
\hline $\begin{array}{l}7.2 \\
9.8 \\
7.4 \\
9.7 \\
8.2 \\
8.2 \\
8.2 \\
6.6 \\
6.6 \\
9.6 \\
7.5 \\
9.7 \\
7.5 \\
9.4 \\
9.4 \\
9.4 \\
9.2 \\
9.9 \\
9.9 \\
7.5 \\
7.6 \\
7.5 \\
9.6\end{array}$ & $\begin{array}{l}8.0 \\
8.3 \\
8.1 \\
8.3 \\
8.2 \\
8.2 \\
- \\
6.6 \\
- \\
8.4 \\
8.1 \\
8.5 \\
8.2 \\
8.3 \\
8.1 \\
8.6 \\
8.4 \\
8.5 \\
8.6 \\
7.8 \\
7.9 \\
-\end{array}$ & $\begin{array}{c}\text { Boiling } \\
\text { Boiling } \\
\text { Boiling } \\
\text { Boiling } \\
90 \\
80 \\
60 \\
90 \\
60 \\
\text { Boiling } \\
\text { Boiling } \\
\text { Boiling } \\
\text { Boiling } \\
\text { Boiling } \\
\text { Boiling } \\
\text { Boiling } \\
\text { Boiling } \\
\text { Boiling } \\
\text { Boiling } \\
\text { Boiling } \\
\text { Boiling } \\
\text { Boiling } \\
\text { Boiling }\end{array}$ \\
\hline 9.6 & - & Boiling \\
\hline $\begin{array}{l}7.2 \\
7.3 \\
7.0 \\
7.9 \\
8.0 \\
7.8 \\
9.5\end{array}$ & $\begin{array}{l}7.3 \\
7.5 \\
7.7 \\
8.0 \\
8.1 \\
7.9 \\
8.4\end{array}$ & $\begin{array}{l}\text { Boiling } \\
\text { Boiling } \\
\text { Boiling } \\
\text { Boiling } \\
\text { Boiling } \\
\text { Boiling } \\
\text { Boiling }\end{array}$ \\
\hline
\end{tabular}

Condenser.

Cold finger

Cold finger

cold finger

Cold finger

Cold finger

None

None

None

None

None

Cold finger

cold finger

Cold finger

Cold finger

cold finger

Cold finger

cold finger

cold finger

Cold finger

cold finger

Allihn

Allihn

Allihn

Allihn

Allinn

Cold finger

Cold "finger

cold $f$ inger

cold finger

Colr finger

Cold finger

Co d finger

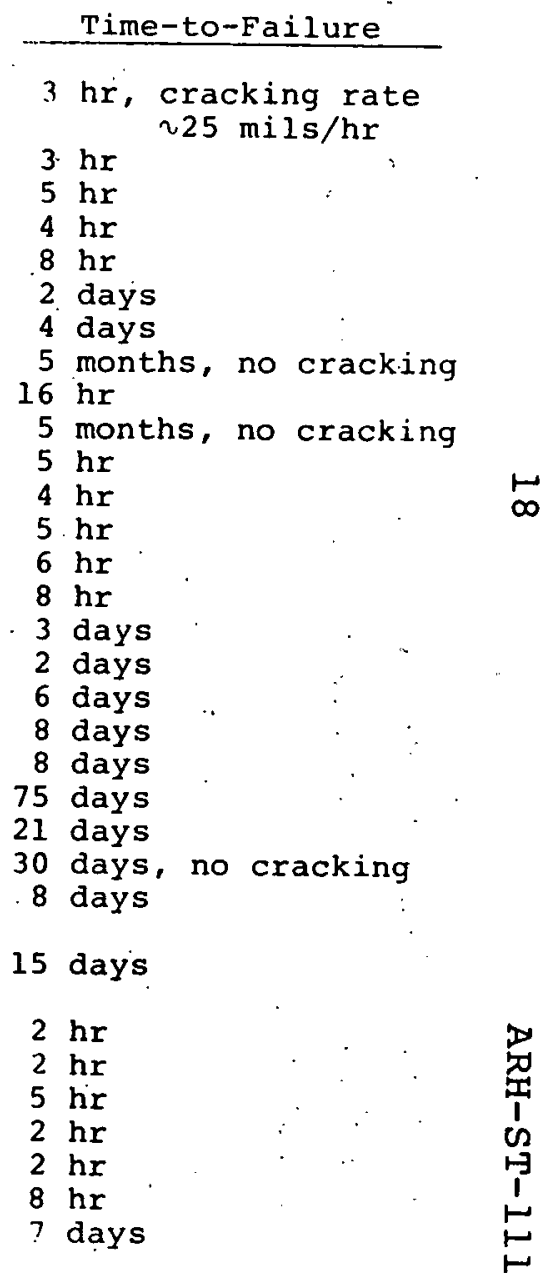


TABLE VII (continued)

Run

No.

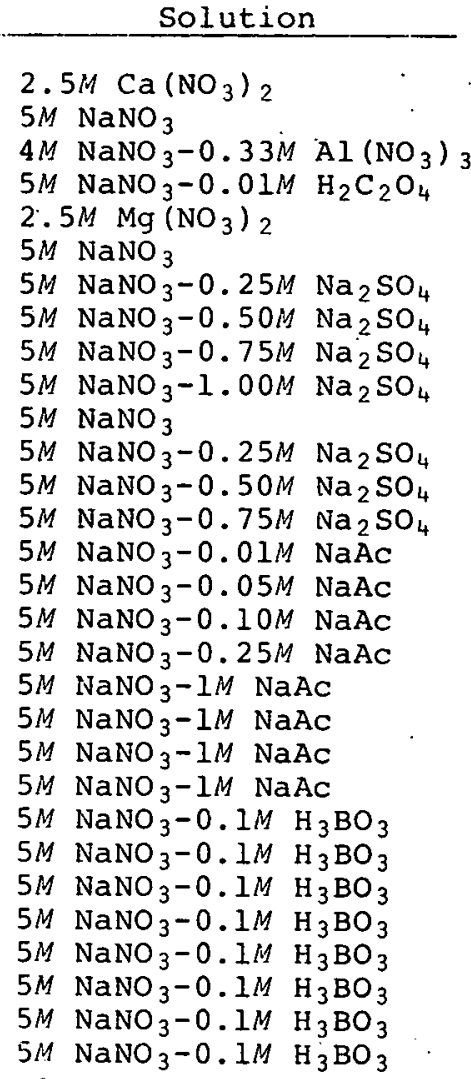

Initial Terminal
$\mathrm{pH}$$\frac{\mathrm{pH}}{\frac{\text { Temperature }}{{ }^{\circ} \mathrm{C}}}$

6.2
4.9
2.3
1.5
5.5
8.4
8.5
8.8
8.8
8.8
11.5
11.5
11.5
11.5
7.5
7.7
8.0
8.1
8.1
9.2
10.4
11.7
5.0
6.0
7.0
8.0
9.0
10.0
11.0
12.0

Boiling

Boiling

Boiling

Boiling
Condenser.

Cold finger cold finger

Cold finger cold finger Cold finger Cold finger Cold finger Cold finger cold finger Cold finger Cold finger cold finger Cold finger Cold finger Cold finger Cold finger Cold finger Cold finger Cold finger Cold finger Cold finger Cold finger Cold finger Cold finger Cold finger Cold finger Cold finger Cold finger cold finger cold finger
Time to lailure

$16 \mathrm{hr}$

3 days

$10 \mathrm{hr}$

1 day

$12 \mathrm{hr}$

2 days

9 days

16 days

17 days

12 days.

90 days, no cracking

9.0 days, no cracking

90 days, no cracking

90 days, no cracking

3 days

3 days

18 days

4 days

30 days, no cracking

30 days, no cracking

30 days, no cracking

30 days; no cracking

$10 \mathrm{hr}$

$14 \mathrm{hr}$

$12 \mathrm{hr}$

4 dàs

10 days ( (1 day)
30 days, no cracking.
30 days, no cracking 
Time-to-failure was evaluated as a function of nitrate concentration between 10 and $0.05 \mathrm{M}$. Cracking occurred at all concentration levels evaluated while the time-to-failure increased from a few hours to about one week as the nitrate concentration decreased from 10 to $0.05 \mathrm{M}$. A plot of nitrate. concentration versus time-to-failure (Figure 1) shows a definite break in the curve between 2 and $1 M$ nitrate ion (Runs 16, 18, and 19). The effect of $\mathrm{pH}$ was also evaluated and the results indicate that no cracking occurred at pH's 11 to 12 (Table VIII). In the pH range 5 to 9 , the time-tofailure rate is not a function of $\mathrm{pH}$.

\section{TABLE VIII}

\section{EFFECT. OF PH ON TIME-TO-FAILURE OF TEST SPECIMENS IN SODIUM NITRATE SOLUTIONS}

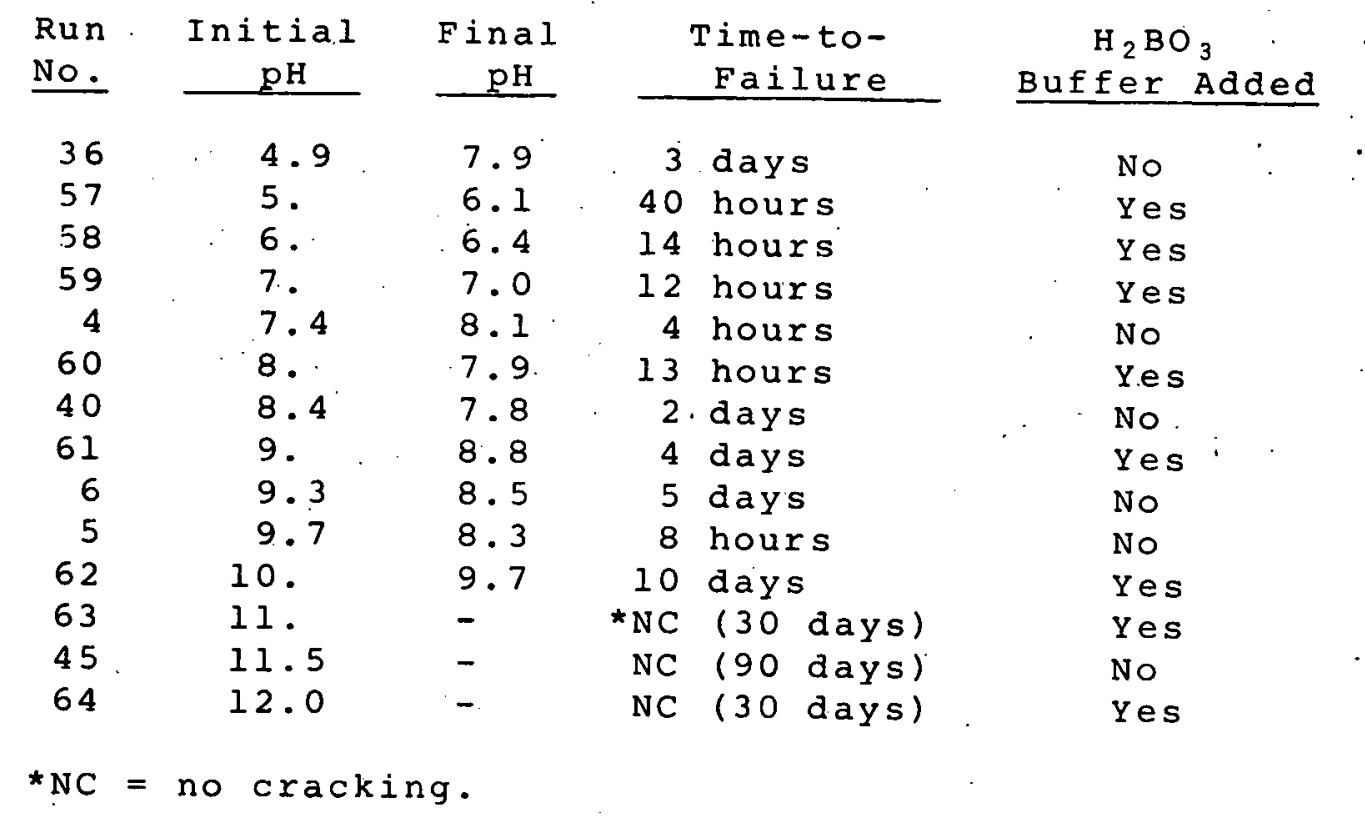

In the $\mathrm{pH}$ range 11 to 13, iron becomes increasingly passive and it could be this surface passivity that is advantageously retarding crack growth rate. In support of this, $2 \% \mathrm{NaOH}$ has been used to inhibit SCC in nitrate solutions. It does appear that at intermediate levels $\mathrm{NaOH}$ can 


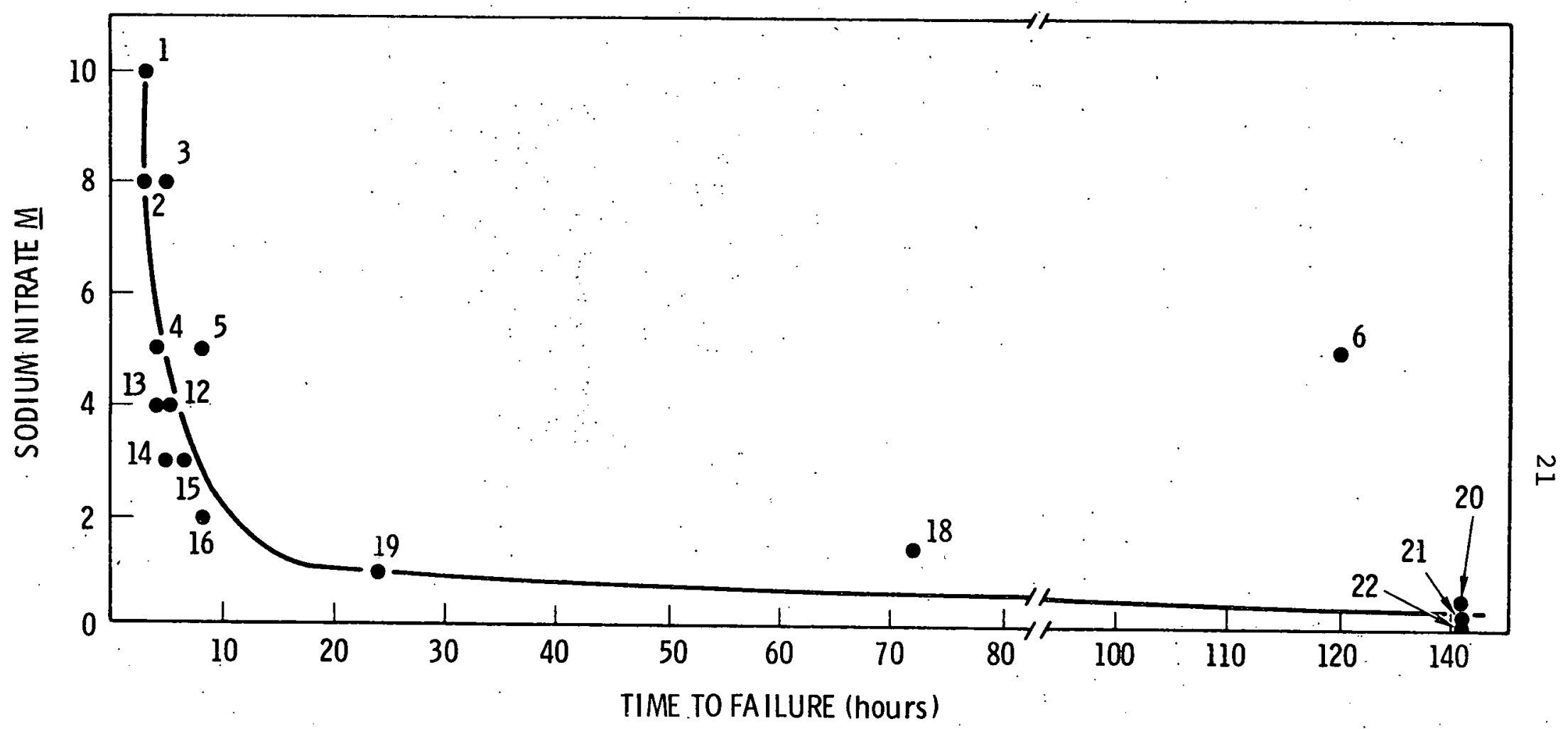

(BOILING TEMPERATURE, COLD FINGER CONDENSER)

\section{FIGURE 1}

RELATIONSHIP BETWEEN TIME TO FAILURE AND SODIUM NITRATE CONCENTRATION 
inhibit SCC by nitrate.

Temperature is the other important factor in stress cracking. Runs 7 through 11 indicate that the propensity to crack is greatly lessened by an incremental decrease in temperature.

\section{SOLIDIFIED HIGH-LEVEL WASTE STUDIES}

When the waste management decision was made to store the radioactive waste in the form of a salt cake rather than a liquid, studies were initiated to define the corrosiveness of solidified high-level, waste. [27] The composition of the test solutions and the results of the first study[28,29] are depicted in Tables IX and $x$. Three corrosion specimens were included in each test: a notched, precracked c-ring fabricated form 1.25". Schedule 90 pipe (ASTM A-106.), a U-bend specimen fabricated from 0.070" sheet (ASTM A-212), and a corrosion specimen fabricated from 0.5" plate (ASTM A-283).

The corrosion rates, as determined by weight loss, varied from 0.2 to $22 \mathrm{mils} /$ year with no clearly defined effect of water content or temperature. Significant pitting occurred on all specimens which evidenced significant general corrosion ( $>2 \mathrm{mils} /$ year): None of the $\mathrm{C}$-rings or U-bend specimens failed via stress corrosion cracking, but the high caustic level could be the reason for this. Caustic as well as nitrate solutions have been the cause of stress corrosion cracking, but as of now the critical levels for a causticnitrate-waste system have not been defined.

As noted in Table $x$, the exposure time is quite variable and reflects the fact that significant deterioration of the test containers (polypropylene jars) occurred. consequently it was not possible to assure a constant water 


\section{TABLE IX}

COMPOSITION OF TEST SOLUTIONS

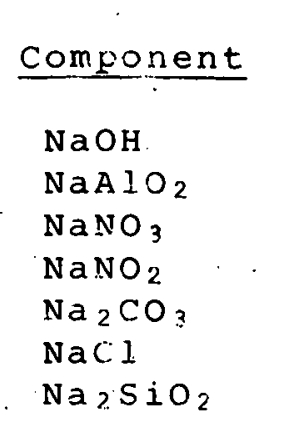

\begin{tabular}{ccr}
\multicolumn{3}{c}{ Solution 1} \\
\cline { 1 - 1 } & g/liter & wt:a \\
10.0 & 400 & 34.0 \\
1.7 & 139 & 12.0 \\
4.3 & 366 & 31.0 \\
1.3 & 90 & 7.6 \\
1.6 & 170 & 14.0 \\
0.2 & 12 & 1.0 \\
0.01 & 1 & 0.1
\end{tabular}

\begin{tabular}{|c|c|c|}
\hline$M$ & g/liter & $w+8$ \\
\hline 5.0 & 200 & 20.0 \\
\hline 1.7 & 139 & 14.0 \\
\hline 4.3 & 366 & 37.0 \\
\hline 1.3 & 90 & 9.2 \\
\hline 1.6 & 170 & 17.0 \\
\hline 0.2 & 12 & 1.2 \\
\hline 0.01 & 1 & 0.1 \\
\hline
\end{tabular}

${ }^{a}$ Dry weight basis.

TABLE X

CORROSION OF MILD STEEL IN SIMULATED HIGH-LEVEL SOLIDIFIED WASTE

\begin{tabular}{|c|c|c|c|c|c|}
\hline $\begin{array}{c}\mathrm{NaOH} \\
\text { Content } \\
\\
\end{array}$ & $\begin{array}{c}\begin{array}{c}\mathrm{H}_{2} \mathrm{O} \\
\text { Content }\end{array} \\
8 \\
\end{array}$ & $\frac{\text { Temperature }}{{ }^{\circ} \mathrm{C}}$ & $\begin{array}{c}\text { Exposure } \\
\text { Time } \\
\text { days } \\
\end{array}$ & $\frac{\text { Corrosion rate, }}{A-283 a}$ & $\frac{\mathrm{mils} / \text { year }}{\mathrm{A}-212 b}$ \\
\hline 20 & 2 & $80^{\circ}$ & 189 & 1.2 & 2.3 \\
\hline 20 & 5 & 60 & 189 & 2.9 & 12.0 \\
\hline 20 & 5 & 80 & 98 & 2.3 & 1.1 \\
\hline 20 & 5 & 90 & 140 & 0.9 & 1.2 \\
\hline 20 & 10 & 60 & 232 & 1.5 & 2.7 \\
\hline 20 & 10 & 80 & 284 & 0.5 & 2.0 \\
\hline 20 & 10 & 90 & 284 & 0.2 & 0.2 \\
\hline 34 & 2 & 60 & 284 & 16.1 & 8.4 \\
\hline 34 & 2 & 80 & 284 & 2.2 & 7.1 \\
\hline 34 & 2 & 90 & 73 & 4.3 & - \\
\hline 34 & 2 & 90 & 189 & 21.0 & 17.6 \\
\hline 34 & 5 & 60 & 140 & 11.3 & 7.9 \\
\hline 34 & 5 & 80 & 140 & 2.1 & 4.0 \\
\hline 34 & 5 & 90 & 73 & 4.0 & - \\
\hline 34 & 10 & 60 & 280 & 18.5 & 9.6 \\
\hline 34 & 10 & 80 & 284 & 1.4 & 4.2 \\
\hline 34 & 10 & 90 & 73 & 1.8 & - \\
\hline 34 & 10 & 90 & 234 & 2.6 & 17.4 \\
\hline$b_{U}-b e$ & $\begin{array}{l}\text { cut from } \\
\text { specimens }\end{array}$ & $\begin{array}{l}0.5 " \text { plat } \\
\text { fabricate }\end{array}$ & $\begin{array}{l}\text { ASTM } \\
\text { from } 0\end{array}$ & $\begin{array}{l}-283, \text { Grade C. } \\
070 " \text { sheet, AS }\end{array}$ & TM A-212. \\
\hline
\end{tabular}


content. This fact and polypropylene decomposition products could have adversely. influenced the test results.

If one ignores the differences in exposure time, which could be an error, and tries to draw some cónclusions from the data, it is apparent that the rate of corrosion for steel exposed to $34 \% \mathrm{NaOH}$ is greater than for steel exposed to $20 \%$ caustic. The range for the former is 1.4 to $21.6 \mathrm{mpy}$ while the latter is 0.2 to $2.9 \mathrm{mpy}$ except for one point at 12.0 mpy. The effect of temperature is actually to decrease the rate of corrosion (Figures 2 and 3 ). This could be due to lower $\mathrm{O}_{2}$ solubility in the liquid or enhanced rate of oxidation of $\mathrm{Fe}^{+2}$ to $\mathrm{Fe}^{+3}$ and the formation of a less permeable diffusion layer on the iron surface. The data also suggested that the rate of corrosion decrease"s with an increase in water content. "This might be explained since an increase in water content from 2 to $10 \%$ causes a corresponding decrease in the basicity of the solution.

A conclusion that might be drawn from this work is that the high levels of base have decreased the propensity to cracking by a significant degree, but have increased the rate of general corrosion and pitting corrosion by at least an order of magnitude. At these high base levels the corrosion product, $\mathrm{Fe}(\mathrm{OH})_{2}$, is amphoteric and dissolves--forming $\mathrm{FeO}_{2}$ - which changes the corrosion potential and hence the rate of corrosion.

A second study[30] in which precautions were taken to insure against container failure was undertaken to evaluate the corrosiveness of solidified high-level wastes. Also systems in which the high caustic content was reduced by neutralization with a polyprotic acid, $\mathrm{H}_{3} \mathrm{PO}_{4}$ or $\mathrm{H}_{2} \mathrm{SO}_{4}$ were evaluated. The waste compositions used are shown in Table XI. The test compositions designated $\mathrm{I}-\mathrm{OH}$ and $\mathrm{II}-\mathrm{OH}$ 


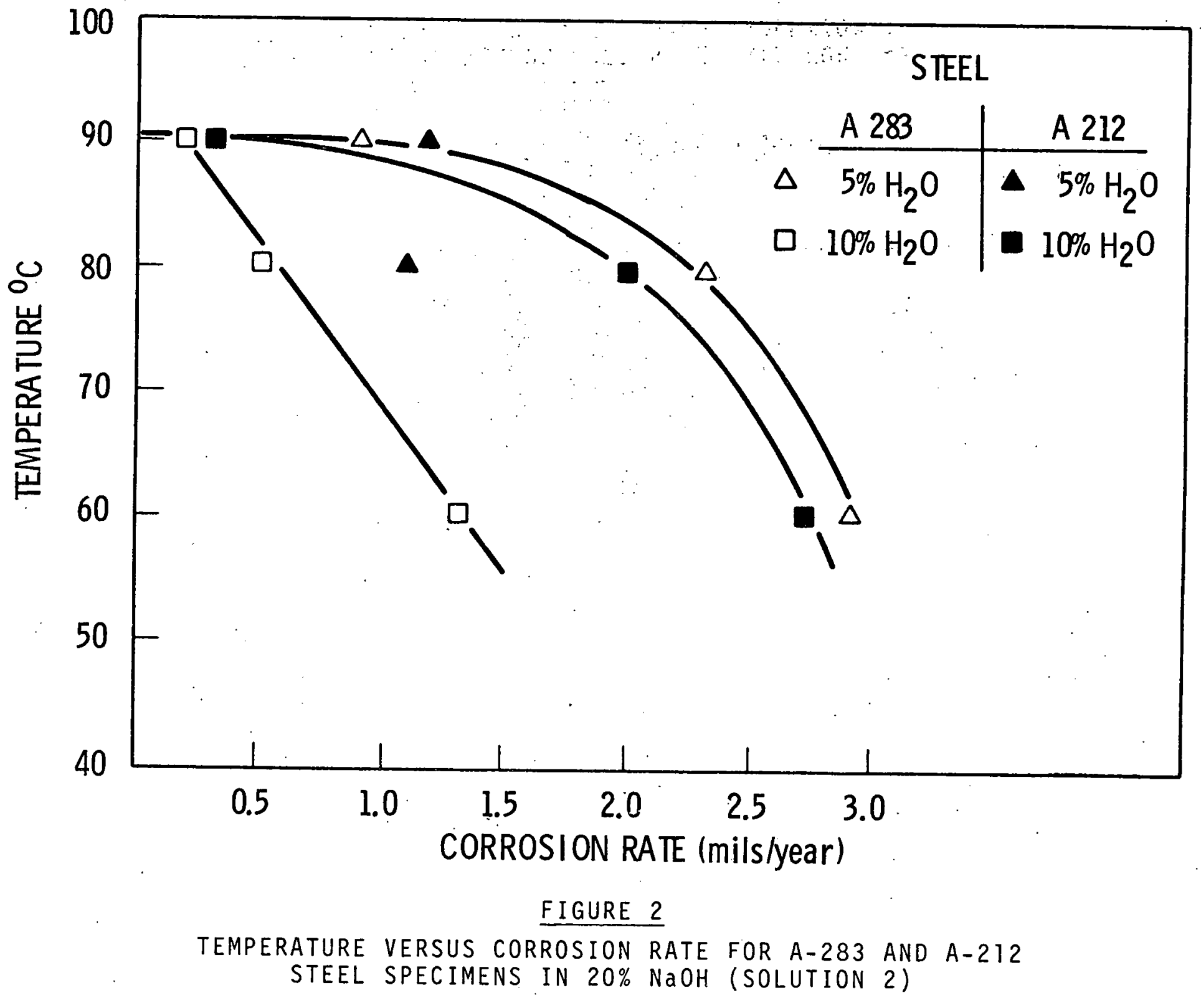




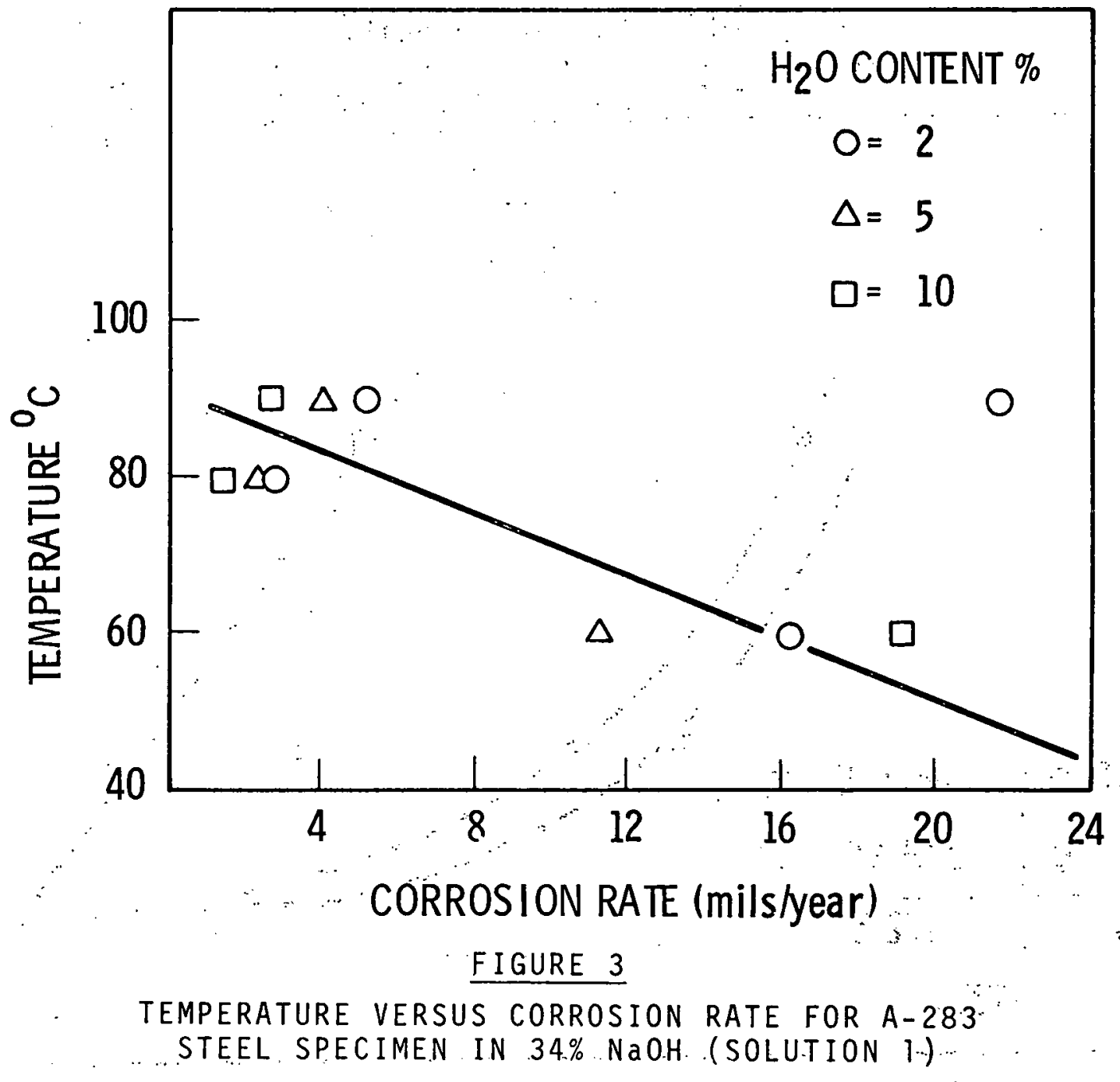


TABLE XI

WASTE COMPOSITIONS

\begin{tabular}{|c|c|c|c|c|c|c|c|c|c|}
\hline & \multicolumn{2}{|c|}{$\mathrm{I}-\mathrm{OH}$} & \multicolumn{2}{|c|}{$\mathrm{II}-\mathrm{OH}$} & \multirow{2}{*}{$\frac{\mathrm{I}-\mathrm{PO}_{4}}{\mathrm{~g} / \text { liter }}$} & \multirow{2}{*}{$\frac{\mathrm{II}-\mathrm{PO}_{4}}{\text { g/liter }}$} & \multirow{2}{*}{$\frac{\mathrm{I}-\mathrm{SO}_{4}}{\text { g/liter }}$} & \multirow{2}{*}{$\frac{\mathrm{I}-\mathrm{NO}_{4}}{\text { g/liter }}$} & \multirow{2}{*}{$\frac{\mathrm{II}^{-\mathrm{NO}_{3}}}{\mathrm{~g} / \text { liter }}$} \\
\hline & g/liter & wt: & g/liter & wt: & & & & & \\
\hline $\mathrm{NaOH}$ & 400 & 34. & 200 & 20: & 40 & 20 & 40 & 40 & 20 \\
\hline $\mathrm{NaAlO}_{2}$ & 139 & 12. & 139 & 14.0 & 139 & 139. & 139 & 139 & 139 \\
\hline $\mathrm{NaNO}_{3}$ & 366 & 31. & 366 & 37.0 & 366 & 366 & 366 & 1131 & 749 \\
\hline $\mathrm{NaNO}_{2}$ & 90 & 7.6 & 90 & 9.2 & 90 & 90 . & 90 & 90 & 90 \\
\hline $\mathrm{Na}_{2} \mathrm{CO}_{3}$ & 170 & 14.0 & 170 & 17.0 & 170 & 170 & 170. & 170 & 170 \\
\hline $\mathrm{NaCl}$ & 12 & 1.0 & 12 & 1.2 & 12 & 12 & 12 & 12 & 12 \\
\hline $\mathrm{Na}_{2} \mathrm{SiO}_{3}$ & 1 & 0.1 & 1 & 0.1 & 1 & 1 & 1 & 1 & 1 \\
\hline $\mathrm{Na}_{3} \mathrm{PO}_{4}$ & - & - & - & - & 492 & 246 & - & - & - \\
\hline $\mathrm{Na}_{2} \mathrm{SO}_{4}^{4}$ & - & - & - & - & - & - & 639 & - & $\therefore$ \\
\hline
\end{tabular}


are the same as those used in the previous study. These wastes were dehydrated at $120^{\circ} \mathrm{C}$, then made up to either 5 or $15 \%$ free water (water in excess of the amount required to form $\mathrm{Na}_{2} \mathrm{CO}_{3} \cdot 1 \mathrm{OH}_{2} \mathrm{O}$ ). It should be mentioned that in the previous study and to an extent in this study the caustic levels are significantly higher than those expected in the salt cake.

Containers were made by welding bottoms on 6" lengths of 2.25" diameter 1020 Schedule 40 pipe: The pipes were threaded and capped after addition of solidified waste and corrosion specimens. The corrosion specimens consisted of coupons (ASTM A-283, grade C) for weight loss determinations, and precracked C-rings to evaluate stress corrosion cracking. The c-rings were fabricated from. 0.5" length of 1.25" diameter Schedule 80 pipe (ASTM A-106, grade B).

A strong odor of ammonia was detected when containers which held "standard" high-alkali waste were opened, indicating that the cathodic reaction could include:

$$
3 \mathrm{Fe}+\mathrm{NaOH}+\mathrm{NaNO}_{2}+3 \mathrm{H}_{2} \mathrm{O} \rightarrow \mathrm{Na}_{2} \mathrm{FeO}_{2}+2 \mathrm{Fe}(\mathrm{OH})_{2}+\mathrm{NH}_{3}
$$

The tests results after one year show that none of the c-ring specimens were cracked. The corrosion rates of the specimens exposed to "standard" waste (Table XII) corroded at rates ranging from 0.4 to $4.2 \mathrm{mils} / \mathrm{year}$. The corrosion rate at $90^{\circ} \mathrm{C}$ is appreciably lower than the rate at $80^{\circ}$ and $60^{\circ} \mathrm{C}$, as suggested by the data in the previous study. These results suggest than an increase in water content from 5 to $15 \%$ increased corrosion by a factor of 2 .

The corrosion rates. for the various "neutralized" waste are low and similar to the early results reported for synthetic liquid waste. Pitting attack occurred on most specimens exposed to standard waste (I-OH and II-OH--Table XIII). 


\section{TABLE XII}

\section{CORROSION RATES OF MILD STEEL EXPOSED TO SOLIDIFIED WASTE}

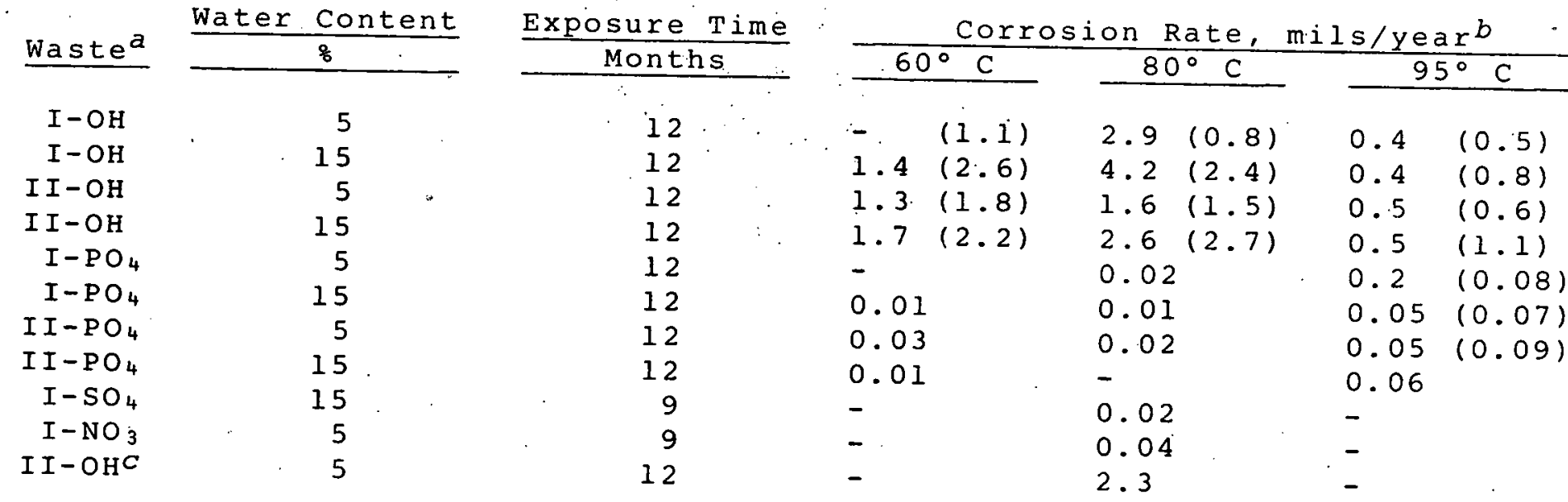

a See Table XI for compositions.

Parenthetical values are 7-month corrosion data.

CPlus $1 \%$ fluoride added as NaF. 
TABLE XIII

PITTING INTENSITY OF MILD STEEL EXPOSED TO SOLIDIFIED WASTE--ONE-YEAR EXPOSURE

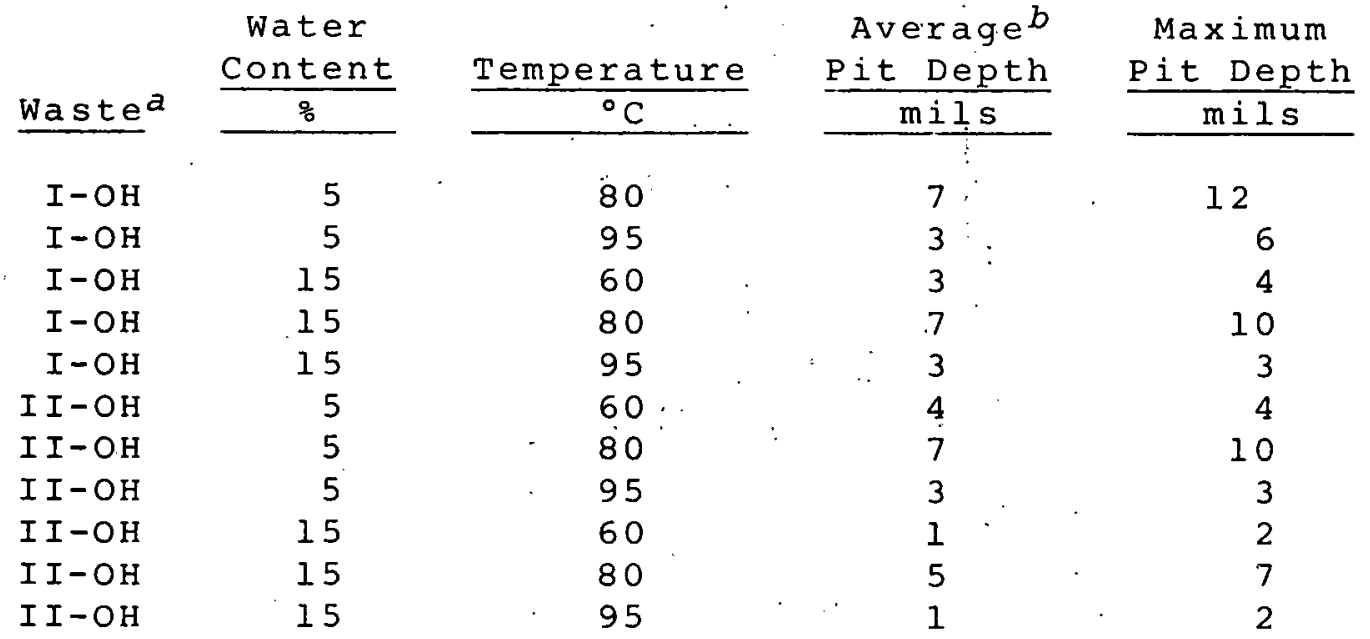

a see Table XI for compositions.

$b_{\text {Average of } 10 \text { pits. }}$

The maximum pit depth after one year was 12 mils, but the average was approximately 4 mils. More severe pitting was found at $80^{\circ}$ than $60^{\circ} \mathrm{C}$ and much more than at $90^{\circ} \mathrm{C}$. The water con ent did not seem to affect the pitting depth.

These results indicate that $\mathrm{SCC}$ is not a problem at high concentrations of caustic, but at these high caustic levels the rates of general corrosion and pitting corrosion do increase. Pitting attack appears to be more serious than previously encountered and is the subject of current research.

\section{CATHODIC PROTECTION STUDIES}

Cathodic protection studies are currently under investigation as a means of decreasing the rate of corrosion of the steel tank liners. [32] The variables in this study include (1) corrosion rate versus current density and time; 
selective attack (pitting and SCC versus current density); (3) polarization versus current density and time; (4) suitable reference electrode, materials compatible with radiation and caustic; (5) suitable anode material, low back emf, low corrosion rate, and good physical properties; and (6) conductivity of salt cake as a function of composition and water content.

Some onsite data have been generated on the feasibility of employing cathodic protection on the steel tank.

liners. $[2,1,33]$ Three tanks (1' $x 1^{\prime} \times 4^{\prime}$ with a 15-gal capacity) were constructed from $0.5^{\prime \prime}$ steel and filled with simulated Purex alkaline waste solution. The solution was $6 \mathrm{~N}$ in nitrate and had a $\mathrm{pH}$ of 10 . Nitrite ion was excluded from the test solution. The tanks were heated to the boiling point of the solutions: A current density of $1 \mathrm{ma} / \mathrm{ft}^{2}$ and $10 \mathrm{ma} / \mathrm{ft}^{2}$ were impressed on Tanks 1 and 2 . Tank 3 was unprotected: The unprotected tank (\#3) failed after five weeks' exposure, and Tank 1 after eight weeks. Tank 2 had not failed after two years, at which time the test was terminated.

\section{ACKNOWLEDGMENTS}

I am indebted to Milton H. Campbell, Ernest L. Moore, and J. Steve Buckingham of Atlantic Richfield Hanford Company and Roy F. Maness of the Battelle Pacific Northwest Laboratories for their comments and suggestions in preparing this document and for discussing their experimental results which are cited in this report. The author also wishes to. express his gratitude to Eleanore Earhart for secretarial help. 


\section{REFERENCES}

1. Progress Report, Separation Development Division, Metallurgical Report, CN-1314, Clinton Laboratories, March 10, 1944.

2: W.W. Koenig, Corrosion Rates of Mizd and Stainzess Steel, HW-14923, General Electric Company, Richland, 1948 .

3. W. W.'Koenig and K. L. Sanborn, Corrosion of Redox Waste Storage Tank Construction Material, HW-18595, General Electric Company, 1950.

4. K. L. Sanborn, A Study of the Effect of $p H$ on First Cycle Bismuth Phosphate Waste on the Corrosion of Mild Steel, HW-26202, General Electric Company, November 13, 1952 .

5. N. D. Groves, Technical Activities Report-Corrosion and Welding - Effect of Lowering the $p H$ in TBP Waste Solution, HW-29183, General Electric Company, August 9, 1958 .

6. E. C. Pitzer, Corrosion Test SAE 1010 Mizd Steel in Synthetic Waste Solution, HW-24136, General Electric Company, April 17, 1952.

7. R. E. Olson, Corrosion Tests SAE 1010 Mizd Steel in Synthetic Neutralized Redox Wastes, HW-26201, General Electric Company, 1954.

8. N. Endow and K. Sanborn, Laboratory Study of the Extent of Pitting and General Corrosion of SAE.1010 Steel in Simulated Neutralized Purex Process Waste Solution, HW-32734, General Electric Company, 1954. 
9. G. R. Mallett, Corrosion Test of Mild Steel in Redox Waste Tank (SAE 1020), HW-33552, General Electric Company, 1954.

10. D. H. Parks, Examination of Corrosion Test Coupons in Purex 101 Waste Storage Tanks RM 147, HW-49574, General Electric Company, 1957.

11.. N. Endow and K. Sanborn, Field Corrosion Test SAE 1020 Carbon Steel in Redox Process Waste Solution Tank 104, 241-S, HW-32755, General Electric Company, 1954.

12. N. Endow, Fiezd Corrosion Tests SAE 1020 Steel in Bismuth Waste Storage Tanks, HW-30641, General Electric Company, January 25, 1954.

13. N. D. Groves, M. C. Fraser, and W. L. Walker, Field Corrosion Tests in Redox and Purex Underground Storage Tanks, :HW-37642, General Electric Company, 1955.

14. K. L. Sanborn and W. R. Smith, Examination of Removable Tube Bundies for Redox, HW-32642, General Electric Company, september 2, 1954.

15. H. H. Hopkins, Jr., ed., Atzantic Richfield Hanford Company Semiannual Report, Research and Development, " November 1, 1972 to April 30, 1973, ARH-2656 B, Atlantic Richfield Hanford Company.

16. N. Endow, Laboratory Corrosion Test of Spring Steel. Wire in Simulated Neutralized Purex waste Solution. HW-29727, General Electric Company, 1953.

17. N. Endow, Corrosion Test of spring Steel, HW-31405, General Electric Company, 1954.

18. R. F. Maness, Stress Corrosion Cracking of Mizd Steel in Nitrate Solutions, HW-78168, General Electric Company, 1963. 
19. E. L. Moore, Stress Corrosion Cracking of A515 Grade 60 Carbon Steel, ARH-1290, Atlantic Richfield Hanford Company, 1971 .

20. L. Costas, M. Holzworth, and W. Rion, Stress Corrosion Cracking of Carbon steel in Simulated Waste solution, DP-1023, Savannah River, 1966.

21. R. E. Isaacson and R. E. Tomlinson, Atiantic Richfiéd Hanford Company Semiannual Report, Research and Development, November 1, 1968. through April 30 i969, ARH-1299 RL-5, Atlantic Richfield Hanford Company, 1969.

22. R. E. Isaacson and R. E. Tomlinson, Atlantic Richfield Hanford Company Semiannual Report, Research and Development, May 1, 1969 through October 31, 1969, ARH-1515 RL-6, Atlantic Richfield Hanford: Company, December 31,1969 .

23. F. W. Albaugh, Pacific Northwest Laboratories Monthly Activities Report September 1970, BNWL-1518, Battelle Pacific Northwest Laboratories, October. 1970.

24. F. W. Albaugh, Pacific Northwest Laboratories Monthiy Activities Report October 1970, BNWL-1535, Battelle Pacific Northwest Laboratories, November 1970.

25. A. E. Smith and R. E. Isaacson, eds., Atlantic Richfield Semiannual Report, Research and Development, May 1, 1971 through october 31, 1971, ARH-2275 A, Atlantic Richfield Hanford Company, 1971.

26. R. S. Paul, Pacific Northwest Laboratories.Monthly Activities Report January 1972, BNWL-1645, Battelle Pacific Northwest Laboratories, February.1972. 
27. R. S. Paul, Pacific Northwest Laboratories Monthly Activities Report December 1971, BNWL-1639, Battelle Pacific Northwest Laboratories, January 1972.

28. R. S. Paul, Pacific Northwest Laboratories Monthly Activities Report June 1971, BNWL-1769, Battelle Pacific Northwest Laboratories, July. 1972.

29. H. H. Hopkins, Jr.; ed., Atiantic Richfiezd Hanford Company Semiannual Report, Research and Development, May 1, 1972 through October 31, 1972, ARH-2656 A, Atlantic Richfield Hanford Company, . December 1972.

30. R. S. Paul, Pacific Northwest Laboratories Monthly Activities Report November 1972, BNWL-1698, Battelle Pacific Northwest Laboratories, December 1972.

31. E. I. Alpen, Pacific Northwest Laboratories Monthly Activities Report.April 1974, BNWL-1830, Battelle Pacific Northwest Laboratories, May 1974.

32. E. L. Alpen, Pacific Northwest Laboratories Monthly Activities Report February 1974, BNWL-1819, Battelle Pacific Northwest Laboratories, March 1974.

33. R. E. Isaacson and R. E. Tomlinson, eds., Atzantic Richfield Hanford Company Semiannual Report, Process Development, November 1, 1970 through Apriz 31, 1971, ARH-1968 B, Atlantic Richfield Hanford Company, 1971. 


\section{DISTRIBUT-ION}

Number of Copies

Battelle Pacific Northwest Laboratories

R.. F. Maness

5 U. S. Energy Research and Development Administration, Richland Operations Office

o. J. Eigert

275

U. S. Energy Research and Development Administration, Technical Information Center; Oak Ridge, TN

H. Babad

C: R. Bergdahl

J. S. Buckingham

G. Burton, Jr.

F. R. Dornineim

J. Faulhaber

D. R. Gustavson (5)

R. D. Fox

J. E. Hammelman

W. M. Harty

H. H. Hopkins, Jr.

W. P. Ingalls

R. E. Isaacson

H. F. Jensen

D. C. Lini (10)

C. W. Malody

E: L. Moore

N. C. Rodewald

H. P. Shaw

G. T. Stocking

D. A. Turner

B. L. Vail

R. E. Van der cook

W. J. Van Slyke

F. R. Vollert

J. H. Warren

R. A. Watrous

D. D. Wodrich

ARHCO Document Services

(3) 